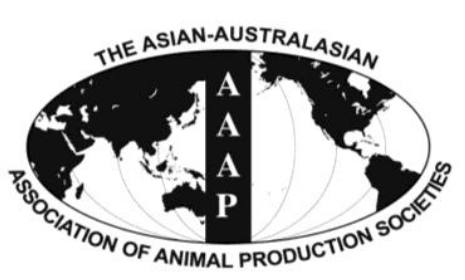

Open Access

Asian Australas. J. Anim. Sci.

Vol. 27, No. 1 : $62-68$ January 2014

http://dx.doi.org/10.5713/ajas.2011.11222

www.ajas.info

pISSN 1011-2367 elSSN 1976-5517

\title{
Effects of Different Dietary Cadmium Levels on Growth and Tissue Cadmium Content in Juvenile Parrotfish, Oplegnathus fasciatus
}

\author{
Okorie E. Okorie, Jun Young Bae, Jun-Ho Lee, Seunghyung Lee, Gun-Hyun Park, \\ Mahmoud Mohseni, and Sungchul C. Bai* \\ Department of Marine Bio-Materials and Aquaculture/Feeds and Foods Nutrition Research Center, \\ Pukyong National University, 599-1 Daeyeon-3-dong, Nam-gu, Busan 608-737, Korea
}

\begin{abstract}
This feeding trial was carried out to evaluate the effects of different dietary cadmium levels on growth and tissue cadmium content in juvenile parrotfish, Oplegnathus fasciatus, using cadmium chloride $\left(\mathrm{CdCl}_{2}\right)$ as the cadmium source. Fifteen fish averaging $5.5 \pm 0.06 \mathrm{~g}$ (mean $\pm \mathrm{SD}$ ) were randomly distributed into each of twenty one rectangular fiber tanks of $30 \mathrm{~L}$ capacity. Each tank was then randomly assigned to one of three replicates of seven diets containing $0.30\left(\mathrm{C}_{0}\right), 21.0\left(\mathrm{C}_{21}\right), 40.7\left(\mathrm{C}_{41}\right), 83.5\left(\mathrm{C}_{83}\right), 162\left(\mathrm{C}_{162}\right)$, $1,387\left(\mathrm{C}_{1,387}\right)$ and $2,743\left(\mathrm{C}_{2,743}\right) \mathrm{mg}$ cadmium/kg diet. At the end of sixteen weeks of feeding trial, weight gain (WG), specific growth rate (SGR) and feed efficiency ( $\mathrm{FE}$ ) of fish fed $\mathrm{C}_{21}$ were significantly higher than those of fish fed $\mathrm{C}_{83}, \mathrm{C}_{162}, \mathrm{C}_{1,387}$ and $\mathrm{C}_{2,743}(\mathrm{p}<0.05$ ). Weight gain, SGR and FE of fish fed $\mathrm{C}_{0}, \mathrm{C}_{21}$ and $\mathrm{C}_{41}$ were significantly higher than those of fish fed $\mathrm{C}_{162}, \mathrm{C}_{1,387}$ and $\mathrm{C}_{2,743}$. Protein efficiency ratio of fish fed $\mathrm{C}_{0}, \mathrm{C}_{21}$ and $\mathrm{C}_{41}$ were significantly higher than those of fish fed $\mathrm{C}_{1,387}$ and $\mathrm{C}_{2,743}$. Average survival of fish fed $\mathrm{C}_{0}, \mathrm{C}_{21}, \mathrm{C}_{41}$ and $\mathrm{C}_{162}$ were significantly higher than that of fish fed $\mathrm{C}_{2,743}$. Tissue cadmium concentrations increased with cadmium content of diets. Cadmium accumulated the most in liver, followed by gill and then muscle. Muscle, gill and liver cadmium concentrations of fish fed $\mathrm{C}_{0}, \mathrm{C}_{21}, \mathrm{C}_{41}$ and $\mathrm{C}_{83}$ were significantly lower than those of fish fed $\mathrm{C}_{162}, \mathrm{C}_{1,387}$ and $\mathrm{C}_{2,743}$. Based on the ANOVA results of growth performance and tissue cadmium concentrations the safe dietary cadmium level could be lower than 40.7 $\mathrm{mg} \mathrm{Cd} / \mathrm{kg}$ diet while the toxic level could be higher than $162 \mathrm{mg} \mathrm{Cd} / \mathrm{kg}$ diet. (Key Words : Dietary Cadmium, Parrotfish, Growth, Tissue Accumulation)
\end{abstract}

\section{INTRODUCTION}

Cadmium is a non-essential and toxic metal that is released into, and distributed, in the aquatic environment by human activities such as mining and smelting. Cadmium can equally contaminate the aquatic environment naturally by leaching of rocks and soil directly exposed to surface water. Cadmium can be absorbed and accumulated in human through consumption of contaminated water, fish and wildlife, and absorbed cadmium is excreted slowly. Basically all major organs are affected by chronic dietary cadmium consumption, with the kidney and the liver as the primary target organs in most species (Swiergosz-

\footnotetext{
* Corresponding Author: Sungchul C. Bai. Tel: +82-51-629-7922, Fax: +82-51-628-6873, E-mail: scbai@pknu.ac.kr

Submitted Jul. 12, 2011; Accepted Sept. 15, 2011; Revised Nov. 7, 2011
}

Kowalewska, 2001). Cadmium toxicosis in the kidney results in proteinuria, glycosuria, amino aciduria, and polyuria while histopathological changes in the liver include intralobular fibrosis, cirrhosis, focal mononuclear infiltration, and proliferation of the smooth endoplasmic reticulum. The toxic effects of cadmium are thought to be caused by free cadmium ions, and cadmium bound to metallothionein is usually less active (Goyer et al., 1989). The mechanism of toxicity of cadmium is linked to cadmium's disruption of the cellular redox state and its structural similarities with divalent cations such as zinc and calcium (Pinot et al., 2000). The redox activity of cadmium depletes antioxidants and glutathione, causes oxidative stress, enhances lipid peroxidation, and alters the lipid composition of membranes. Cadmium-induced reactive oxygen intermediates can lead to decreased DNA synthesis and strand breaks. 
Although water-borne exposure is considered more toxic than dietary cadmium, diet is still a significant route of cadmium contamination. Phosphate sources used in animal diets are likely sources of cadmium contamination. Inorganic sources of dietary cadmium such as chloride, nitrate, acetate, and sulfate, are more available than organic sources such as metallothionein-bound cadmium (Groten et al., 1990; 1994). In fish, the deposition of cadmium is usually highest in the gills, kidney and liver. Kay et al. (1986) reported that more than $90 \%$ of the total whole body cadmium in rainbow trout exposed to high levels of cadmium is found in these three tissues. Cadmium accumulation in Atlantic salmon was highest in the liver, followed by the intestine and then the gills, and rates of apoptosis and cell proliferation in the intestine increased following exposure to dietary cadmium (Lundebye et al., 1999). As animals are able to tolerate levels of cadmium in their diet that result in accumulation of cadmium in their kidneys and livers at concentrations that could be toxic to humans consuming foods made from these organs, it is advisable that maximum dietary levels in the feed of animals used for human food be set on the basis of human health rather than animal health. The upper limit for cadmium in complete feeds for animals has been set by the World Health Organization at $1 \mathrm{mg} / \mathrm{kg}$ diet (IPCS, 1992). The toxicity of cadmium in water appears to be very similar to that in feed (NRC, 2005). The toxicity is variable, freshwater species being more susceptible, but cadmium at a level of $1 \mu \mathrm{g} / \mathrm{L}$ is tolerated by all species in all water conditions.

Parrotfish, Oplegnathus fasciatus, is one of the emerging aquaculture species in the Republic of Korea. Its high commercial value makes it a promising aquaculture species in the future. Currently, the Republic of Korea is the fifth largest parrotfish producer in the world. Unfortunately, little research has been done in this species. In line with the dearth of research in parrotfish, the effects of dietary cadmium levels on this species have not been studied. Therefore, the objective of this study is to evaluate the effects of dietary cadmium levels on growth and tissue cadmium contents in juvenile parrotfish, Oplegnathus fasciatus, using cadmium chloride $\left(\mathrm{CdCl}_{2}\right)$ as the cadmium source.

\section{MATERIALS AND METHODS}

\section{Experimental diets}

Seven semi-purified experimental diets with average protein and crude lipid levels (dry matter) of $41.9 \pm 1.19 \%$ and $9.06 \pm 0.22 \%$ (mean $\pm \mathrm{SD})$, respectively were formulated to contain $0,20,40,80,160,1,600$ and $3,200 \mathrm{mg}$ cadmium $/ \mathrm{kg}$ diet in the form of cadmium chloride $\left(\mathrm{CdCl}_{2}\right)$. However, the analyzed cadmium levels were $0.30\left(\mathrm{C}_{0}\right), 21.0$
$\left(\mathrm{C}_{21}\right), 40.7\left(\mathrm{C}_{41}\right), 83.5\left(\mathrm{C}_{83}\right), 162\left(\mathrm{C}_{162}\right), 1,387\left(\mathrm{C}_{1,387}\right)$ and $2,743\left(\mathrm{C}_{2,743}\right) \mathrm{mg} \mathrm{Cd} / \mathrm{kg}$ diet. Casein and fish meal were used as the protein sources in the diets; wheat flour, dextrin, and corn starch as the carbohydrate sources; and fish oil as the lipid source. Dietary formulation and proximate composition of the basal experimental diet are shown in Table 1.

Diets were prepared by mixing the dry ingredients in an electric mixer, followed by the addition of oil and water. This mixture was formed into dough, and dry pellets were made by passing the dough through a screw type pelleting machine and air drying the formed pellets for approximately $48 \mathrm{~h}$.

\section{Experimental fish and feeding trial}

A feeding trial was carried out at the Feeds and Foods Nutrition Research Center, Pukyong National University, Busan. Fish were transported to the experimental station and acclimated to the experimental conditions for two weeks before the feeding trial began. During this period, fish were fed cadmium-free diet to deplete the body cadmium reserve. The feeding trial was conducted by using the recirculating system with twenty one $30-\mathrm{L}$ aquaria receiving filtered seawater at the rate of $0.8 \mathrm{~L} / \mathrm{min}$ from the center tank. Seawater temperature was maintained at $20 \pm 1^{\circ} \mathrm{C}$ by heaters in the center tank during the whole

Table 1. Dietary formulation and proximate composition of the basal diet (\% DM)

\begin{tabular}{lc}
\hline Ingredient & $\%$ \\
\hline Casein $^{1}$ & 30.0 \\
Fishmeal $^{2}$ & 28.0 \\
Wheat flour $^{3}$ & 10.0 \\
Dextrin $^{1}$ & 10.0 \\
Corn starch $^{2}$ & 5.0 \\
Fish oil $^{4}$ & 8.00 \\
Vitamin premix $^{5}$ & 3.00 \\
Mineral premix (Cadmium-free) $^{6}$ & 3.00 \\
Cellulose (Alpha) $^{1}$ & 3.00 \\
Cadmium premix (ppm) $_{\text {Proximate composition }}$ & 0.00 \\
$\quad$ Moisture & \\
Crude protein & 8.32 \\
Crude lipid & 41.9 \\
\hline
\end{tabular}

${ }^{1}$ United States Biochemical, Cleveland, Ohio 44122.

${ }^{2}$ Su Hyup Feed Co., Uiryeong, Republic of Korea.

${ }^{3}$ Young Nam Flour Mills Co., Busan, Republic of Korea.

${ }^{4}$ E-Wha Oil Co. Ltd., Busan, Republic of Korea.

${ }^{5}$ Contains (as g/100 g premix): dl-calcium pantothenate, 0.5 ; inositol, 0.5 ; menadione, 0.02 ; niacin, 0.5 ; pyridoxine-HCL, 0.05 ; riboflavin, 0.1 ; thiamine mononitrate, 0.05 ; retinyl acetate, 0.02 ; biotin, 0.005 ; folic acid, 0.018; $\mathrm{B}_{12}, 0.0002$; cholecalciferol, 0.008; alpha-cellulose, 98.18.

${ }^{6}$ Contains (as mg/kg diet): $\mathrm{Al}, 1.2 ; \mathrm{Ca}, 5,000 ; \mathrm{Cl}, 100 ; \mathrm{Cu}, 5.1 ; \mathrm{Co}, 9.9$; Na, 1,280; Mg, 520; P, 5,000; K, 4,300; Zn, 27; Fe, 40.2; I, 4.6; Se, 0.2; Mn, 9.1. 
Table 2. Effects of the seven dietary cadmium levels on growth performance of juvenile parrotfish, Oplegnathus fasciatus, fed the experimental diets ${ }^{1}$

\begin{tabular}{|c|c|c|c|c|c|c|c|c|}
\hline & \multicolumn{7}{|c|}{ Diets } & \multirow{2}{*}{ Pooled SEM ${ }^{6}$} \\
\hline & $\mathrm{Cd}_{0}$ & $\mathrm{Cd}_{21}$ & $\mathrm{Cd}_{41}$ & $\mathrm{Cd}_{83}$ & $\mathrm{Cd}_{162}$ & $\mathrm{Cd}_{1,387}$ & $\mathrm{Cd}_{2,743}$ & \\
\hline$\overline{W G^{2}}$ & $96.7^{\mathrm{ab}}$ & $110^{\mathrm{a}}$ & $100^{\mathrm{ab}}$ & $57.6^{\mathrm{bc}}$ & $49.4^{c}$ & $38.0^{\mathrm{c}}$ & $27.0^{\mathrm{c}}$ & 8.24 \\
\hline $\mathrm{SGR}^{3}$ & $0.59^{\mathrm{ab}}$ & $0.64^{\mathrm{a}}$ & $0.60^{\mathrm{a}}$ & $0.40^{\mathrm{bc}}$ & $0.35^{\mathrm{c}}$ & $0.28^{\mathrm{c}}$ & $0.21^{\mathrm{c}}$ & 0.04 \\
\hline $\mathrm{FE}^{4}$ & $31.8^{\mathrm{ab}}$ & $34.8^{\mathrm{a}}$ & $33.1^{\mathrm{ab}}$ & $22.7^{\mathrm{bc}}$ & $20.0^{\mathrm{c}}$ & $16.4^{\mathrm{c}}$ & $12.7^{\mathrm{c}}$ & 2.19 \\
\hline $\mathrm{PER}^{5}$ & $0.74^{\mathrm{ab}}$ & $0.82^{\mathrm{a}}$ & $0.78^{\mathrm{ab}}$ & $0.54^{\mathrm{bc}}$ & $0.50^{\mathrm{bc}}$ & $0.39^{\mathrm{c}}$ & $0.31^{\mathrm{c}}$ & 0.05 \\
\hline Survival (\%) & $68.9^{\mathrm{a}}$ & $71.1^{\mathrm{a}}$ & $71.1^{\mathrm{a}}$ & $53.3^{\mathrm{ab}}$ & $66.7^{\mathrm{a}}$ & $46.7^{\mathrm{ab}}$ & $31.1^{\mathrm{b}}$ & 4.19 \\
\hline
\end{tabular}

${ }^{1}$ Values are means from triplicate groups of fish where the means in each row with different superscripts are significantly different $(\mathrm{p}<0.05)$.

${ }^{2}$ Weight gain $(\%)=($ final weight-initial weight $) \times 100 /$ initial weight. ${ }^{3}$ Specific growth rate $(\%)=\left(\log _{\mathrm{e}}\right.$ final wt- $\log _{\mathrm{e}}$ initial wt $) / \mathrm{d}$.

${ }^{4}$ Feed efficiency $(\%)=$ wet weight gain $(\mathrm{g}) \times 100 /$ dry feed intake $(\mathrm{g}) .{ }^{5}$ Protein efficiency ratio: wet weight gain/protein intake.

${ }^{6}$ Pooled standard error of means: $\mathrm{SD} / \sqrt{n}$.

experimental period. Supplemental aerations were provided to maintain dissolved oxygen levels near saturation $(6.5 \pm 0.5$ $\mathrm{ppm})$ and the salinity of the seawater was $33 \pm 1 \mathrm{~g} / \mathrm{L}$. Fifteen fish of initial average weight $5.5 \pm 0.06 \mathrm{~g}(\mathrm{mean} \pm \mathrm{SD})$ were randomly distributed into each of 21 tanks. Each tank was then randomly assigned to one of three replicates of 7 diets. Triplicate groups of fish were fed each experimental diet to satiation (approximately $4 \%$ of wet body weight per day at the beginning and 3\% of wet body weight per day at the end of the feeding trial). Fish were fed twice a day at 1000 and $1600 \mathrm{~h}$ for $16 \mathrm{wk}$. During the feeding, the water circulation was stopped for $30 \mathrm{~min}$ to enhance ingestion and to reduce carryover of cadmium from one tank to the other. Feeding was done slowly and carefully to ensure that no uneaten food remained in the tanks during feeding, thus leaching of $\mathrm{Cd}$ into water was very low and negligible. Before restarting water circulation, tanks were siphoned and water in the center tank was completely replaced in the evening. Total body weight in each tank was determined every two weeks and the amount of diet fed to the fish was adjusted accordingly.

\section{Sample collection and analysis}

At the end of the feeding trial the total number and weight of fish in each tank were counted and measured for weight gain (WG), specific growth rate (SGR), feed efficiency (FE), protein efficiency ratio (PER), and survival. Samples of gill, liver and muscle tissues were taken for determination of cadmium concentration in the respective tissues. Tissue cadmium contents were determined by microdigestion of samples in nitric acid according to the standard methods of AOAC (1995).

\section{Statistical analysis}

All data were analyzed by one-way ANOVA to test for the effects of the dietary treatments. When a significant treatment effect was observed, a Least Significant Difference (LSD) test was used to compare means. Treatment effects were considered at $p<0.05$ level of significance. All statistical analyses were carried out by SAS Version 9.0 software (SAS Institute, Inc., Cary, NC, USA).

\section{RESULTS}

Weight gain (WG), specific growth rate (SGR), feed efficiency (FE), Protein efficiency ratio (PER) and survival of parrotfish fed the experimental diets are shown in Table 2. Weight gain, SGR, and FE of fish fed $\mathrm{C}_{0}, \mathrm{C}_{21}$ and $\mathrm{C}_{41}$ were significantly higher than those of fish fed $\mathrm{C}_{162}, \mathrm{C}_{1,387}$ and $\mathrm{C}_{2,743}(\mathrm{p}<0.05)$. There were no significant differences in these parameters among fish fed $\mathrm{C}_{0}, \mathrm{C}_{21}$ and $\mathrm{C}_{41}$ or among those fed $\mathrm{C}_{83}, \mathrm{C}_{162}, \mathrm{C}_{1,387}$ and $\mathrm{C}_{2,743}$. Also, there were no significant differences in WG and $\mathrm{FE}$ among fish fed $\mathrm{C}_{0}$, $\mathrm{C}_{41}$ and $\mathrm{C}_{83}$. Protein efficiency ratio of fish fed $\mathrm{C}_{0}, \mathrm{C}_{21}$ and $\mathrm{C}_{41}$ were significantly higher than those of fish fed $\mathrm{C}_{1,387}$ and $\mathrm{C}_{2,743}$. There were no significant differences in PER among fish fed $\mathrm{C}_{0}, \mathrm{C}_{21}$ and $\mathrm{C}_{41}$, among fish fed $\mathrm{C}_{0}, \mathrm{C}_{41}, \mathrm{C}_{83}$ and $\mathrm{C}_{162}$ and among those fed $\mathrm{C}_{83}, \mathrm{C}_{162}, \mathrm{C}_{1,387}$ and $\mathrm{C}_{2,743}$. There were no significant differences in survival of fish in

Table 3. Cadmium accumulation ( $\mathrm{mg} / \mathrm{kg} \mathrm{DM})$ in muscle, gills and liver of juvenile parrotfish, Oplegnathus fasciatus, fed the experimental diets ${ }^{1}$

\begin{tabular}{lcccccccc}
\hline & \multicolumn{9}{c}{ Diets } & & \multirow{2}{*}{ Pooled SEM $^{2}$} \\
\cline { 2 - 8 } & $\mathrm{Cd}_{0}$ & $\mathrm{Cd}_{21}$ & $\mathrm{Cd}_{41}$ & $\mathrm{Cd}_{83}$ & $\mathrm{Cd}_{162}$ & $\mathrm{Cd}_{1,387}$ & $\mathrm{Cd}_{2,743}$ & 0.03 \\
Muscle & $0.10^{\mathrm{c}}$ & $0.10^{\mathrm{c}}$ & $0.09^{\mathrm{c}}$ & $0.14^{\mathrm{c}}$ & $0.20^{\mathrm{b}}$ & $0.37^{\mathrm{a}}$ & $0.33^{\mathrm{a}}$ & 0.03 \\
Gill & $1.68^{\mathrm{b}}$ & $1.50^{\mathrm{b}}$ & $1.98^{\mathrm{b}}$ & $1.43^{\mathrm{b}}$ & $2.57^{\mathrm{a}}$ & $2.83^{\mathrm{a}}$ & $2.89^{\mathrm{a}}$ & 0.14 \\
Liver & $12.7^{\mathrm{d}}$ & $25.9^{\mathrm{d}}$ & $36.9^{\mathrm{d}}$ & $54.2^{\mathrm{d}}$ & $117^{\mathrm{c}}$ & $304^{\mathrm{b}}$ & $411^{\mathrm{a}}$ & 33.1 \\
\hline
\end{tabular}

${ }^{1}$ Values are means from triplicate groups of fish where the means in each row with different superscripts are significantly different $(\mathrm{p}<0.05)$.

${ }^{2}$ Pooled standard error of means: $\mathrm{SD} / \sqrt{n}$. 
all treatments except for survival of fish fed $\mathrm{C}_{2,743}$, which was significantly lower than those of fish fed $\mathrm{C}_{0}, \mathrm{C}_{21}, \mathrm{C}_{41}$ and $\mathrm{C}_{162}$.

Table 3 shows cadmium accumulation in muscle, gill and liver of parrotfish fed the experimental diets. Muscle cadmium contents of fish fed $\mathrm{C}_{1,387}$ and $\mathrm{C}_{2,743}$ were significantly higher than those of fish fed $\mathrm{C}_{0}, \mathrm{C}_{21}, \mathrm{C}_{41}, \mathrm{C}_{83}$ and $\mathrm{C}_{162}$. Muscle cadmium content of fish fed $\mathrm{C}_{162}$ was significantly higher than those of fish fed $\mathrm{C}_{0}, \mathrm{C}_{21}, \mathrm{C}_{41}$ and $\mathrm{C}_{83}$. There were no significant differences in cadmium content of muscle among fish fed $\mathrm{C}_{0}, \mathrm{C}_{21}, \mathrm{C}_{41}$ and $\mathrm{C}_{83}$ or among those fed $\mathrm{C}_{1,387}$ and $\mathrm{C}_{2,743}$. Gill cadmium contents of fish fed $\mathrm{C}_{162}, \mathrm{C}_{1,387}$ and $\mathrm{C}_{2,743}$ were significantly higher than those of fish fed $\mathrm{C}_{0}, \mathrm{C}_{21}, \mathrm{C}_{41}$ and $\mathrm{C}_{83}(\mathrm{p}<0.05)$. There were no significant differences in gill cadmium content among fish fed $\mathrm{C}_{0}, \mathrm{C}_{21}, \mathrm{C}_{41}$ and $\mathrm{C}_{83}$ or among those fed $\mathrm{C}_{162}, \mathrm{C}_{1,387}$ and $\mathrm{C}_{2,743}$. Liver cadmium content of fish fed $\mathrm{C}_{2,743}$ was significantly higher than those of fish fed $\mathrm{C}_{0}, \mathrm{C}_{21}, \mathrm{C}_{41}, \mathrm{C}_{83}$, $\mathrm{C}_{162}$ and $\mathrm{C}_{1,387}(\mathrm{p}<0.05)$. Also, liver cadmium concentration of fish fed $\mathrm{C}_{162}$ was significantly higher than those of fish fed $\mathrm{C}_{0}, \mathrm{C}_{21}, \mathrm{C}_{41}$ and $\mathrm{C}_{83}$. There were no significant differences in liver cadmium content among fish fed $\mathrm{C}_{0}, \mathrm{C}_{21}$, $\mathrm{C}_{41}$ and $\mathrm{C}_{83}$. These results suggest that the dietary cadmium toxicity level could be higher than $162 \mathrm{mg} / \mathrm{kg}$ diet in parrotfish.

\section{DISCUSSION}

Results suggested that growth and survival may not be good indicators of dietary cadmium toxicity in parrotfish over a relatively short period of time and with moderate concentrations of cadmium in diets in parrotfish. Dietary cadmium levels of up to $40.7 \mathrm{mg} / \mathrm{kg}$ diet had little effects on growth performance of parrotfish reared for sixteen weeks in this feeding trial. Beyond this level growth began to decline with increase in dietary cadmium content. Exposure to elevated concentrations of dietary cadmium had no effect on growth in salmon, Salmo salar, parr exposed to 0 to 250 $\mathrm{mg} \mathrm{Cd} / \mathrm{kg}$ diet for four months (Lundebye et al., 1999). No mortality was recorded during chronic exposure (45 or 52 d) of adult rainbow trout, Oncorhynchus mykiss, to 500 $\mathrm{mg} \mathrm{Cd} / \mathrm{kg}$ diet (Chowdhury et al., 2004; Chowdhury and Wood, 2007). Exposure to diets with 300 to $500 \mu \mathrm{g} \mathrm{Cd} / \mathrm{g}$ for 4 wk did not affect the survival and growth of rainbow trout (Baldisserotto et al., 2005; Franklin et al., 2005); and $35 \mathrm{~d}$ exposure to $10 \mu \mathrm{g} \mathrm{Cd} / \mathrm{g}$ tropical fish flakes did not cause any mortality in the tilapia, Oreochromis mossambicus (Pratap et al., 1989).

On the contrary, there were decreased food intake, growth and locomotion activity in fish fed $\mathrm{C}_{2,743}$. Although reduced growth was also recorded in fish fed $\mathrm{C}_{162}$ and $\mathrm{C}_{1,387}$ sluggish movements and poor food acceptance were very pronounced in fish fed $\mathrm{C}_{2,743}$. This indicates that dietary levels of cadmium much higher than values obtainable in feed or in the wild under normal situations might be necessary to elicit toxicity signs in terms of reduced growth and survival in parrotfish within a period of about four months. There have been other studies in which growth inhibition, mortality or reduced locomotion activity has been recorded only at high dietary cadmium inclusion or after feeding for a relatively long time. Szczerbik et al. (2006) recorded visible growth inhibition only in goldfish, Carassius auratus gibelio B., fed the highest cadmium level (10 mg Cd/g diet) while fish fed $0.1 \mathrm{mg} \mathrm{Cd} / \mathrm{g}$ diet actually had better growth than the control group in their study. Only after 6 months could Nogami et al. (2000) observe a small effect on size and weight in tilapia, Oreochromis niloticus, fed $5 \mathrm{mg} \mathrm{Cd} / \mathrm{kg}$ diet for three years. Similar to the results of Szczerbik et al. (2006), it is interesting to note that although there were no significant differences among fish fed 0-40.7 $\mathrm{mg} \mathrm{Cd} / \mathrm{kg}$ diet in this study, there was a trend toward improvement in growth performance of fish fed $21 \mathrm{mg}$ $\mathrm{Cd} / \mathrm{kg}$ diet as compared to the control group. It has been reported that very low cadmium concentration could stimulate DNA synthesis and cell growth (Von Zglinicki et al., 1992). Furthermore, Robohm (1986) showed that stress caused by a low concentration of cadmium in water could cause an increase in antibody number, improving (in some species) the immunological response. Similar to the findings in fish, a number of studies with rodents, chickens, and livestock have reported increased weight gain when low levels of cadmium were added to the diets (Bokori and Fekete, 1995). Although cadmium has been shown to be not only nonessential but toxic in animals, there might be the need to research on the tendency toward growth improvement at low cadmium supplementation in diets if the trend continues in other studies. Based on ANOVA results of growth performance in this study the safe dietary cadmium level could be less than $40.7 \mathrm{mg} / \mathrm{kg}$ diet.

Tissue cadmium concentrations increased with dietary cadmium content. Cadmium accumulated mostly in liver, followed by gill and then muscle. Whole-body and tissue cadmium concentrations have been shown to increase with cadmium content of food or rearing water and duration of exposure (Kumada et al., 1980; Harrison and Klaverkamp, 1989; Kraal et al., 1995; Berntssen et al., 2001; Kim et al., 2006; Ng and Wood, 2008). Furthermore, cadmium accumulation has been reported to vary from organ to organ (Giles, 1988; Hollis et al., 1999, 2001; McGeer et al., 2000; Szebedinszsky et al., 2001; Baldisserotto et al., 2004; Kim et al., 2006). Ng and Wood (2008) reported that the gut had the highest $\mathrm{Cd}$ concentration, followed sequentially by the kidney, liver, gill and carcass in rainbow trout, Oncorhynchus mykiss, fed the oligochaete, Lumbriculus variegatus, exposed to different concentrations of waterborne $\mathrm{Cd}$. Similar results were obtained in rainbow 
trout (Kumada et al., 1980; Crespo et al., 1986; Handy, 1993), Carp (Kraal et al., 1995), Atlantic salmon (Berntssen et al., 2001) and Korean rockfish, Sebastes schlegeli (Kim et al., 2006). Cadmium concentration of intestine was not measured in our study but the concentration in liver, gill and muscle followed the same trend as the above studies. In fish the liver and kidney generally tend to concentrate metals, and play a major role in detoxification and excretion of metals through induction of metal-binding proteins such as metallothioneins. Metallothionein has been reported to be closely related to heavy metal exposure and metal taken up from the environment can be detoxified by binding to this protein (Roesijadi and Robinson, 1994). Conversely, it has been suggested that fish muscle contains extremely low concentration of $\mathrm{Cd}$ because this metal is essentially accumulated in kidney and liver (Cinier et al., 1999). Galar Burgos and Rainbow (2001) proposed that muscle metal concentration may be regulated and is poor biomonitor of $\mathrm{Cd}$ accumulation in the immediate ambient environment. Although cadmium content of muscle was very low, it is important to note that muscle constitutes a large percentage of whole-body of fish and hence, accounts for a substantial proportion of the entire cadmium content of the fish. Moreover, since muscle is usually the edible part of fish, it is necessary that care be taken to ensure that the cadmium content of muscle is below detectable levels.

The absence of growth inhibition or significant mortality in medium-term or low level dietary cadmium exposure could pose some risks to human, as a moderate cadmium contamination might pass along the food chain undetected. It is well known that cadmium is toxic to humans and animals (Hinkle et al., 1987; Roesijadi and Unger, 1993; Goering et al., 1995). Due to its toxicity, maximum permitted concentrations of cadmium in food and feed have been set by regulations to protect animal health and consumer safety. For instance, the maximum permitted concentration in fish feed as set by the European Union is $0.5 \mathrm{mg} / \mathrm{kg}$ dry weight (Lundebye et al., 1999) while the upper limit in complete feeds for animals is set at $1 \mathrm{mg} / \mathrm{kg}$ by the World Health Organisation (IPCS, 1992). In this study significant growth inhibition and tissue cadmium accumulation were observed only in fish fed diets with cadmium concentrations up to $162 \mathrm{mg} / \mathrm{kg}$ diet. Also results suggested dietary cadmium levels below $40.7 \mathrm{mg} / \mathrm{kg}$ to be safe in parrotfish. These levels are much higher than that permitted by the EU. As high accumulation of cadmium may occur in fish before visible signs such as growth inhibition, it is recommended that parameters and methods other than growth and survival, such as enzyme assay be relied upon as early warning signs of adverse effects of this metal on aquaculture organisms. Future studies employing such methods could throw lights on the mechanism involved in the apparent improvement in growth performance with low dietary cadmium supplementation.

In conclusion, results indicate that growth and survival may not be good early warning signs of cadmium toxicity and suggest the reliance upon other methods and parameters such as enzyme assay. Conversely, there was a tendency toward improved performance in fish fed the diet with the lowest level of cadmium supplementation as compared to the control group, a trend that has been observed in other species and should be researched on. Based on the ANOVA results of growth performance and tissue cadmium concentrations the safe dietary cadmium level could be lower than $40.7 \mathrm{mg} \mathrm{Cd} / \mathrm{kg}$ diet while the toxic level could be higher than $162 \mathrm{mg} \mathrm{Cd} / \mathrm{kg}$ diet.

\section{ACKNOWLEDGEMENTS}

This work was supported by the National Research Foundation of Korea (NRF) grant funded by the Korea government (MEST) (No. R01-2007-0053806) and partially supported by the Novus International graduate student scholarship at Feeds and Foods Nutrition Research Center (FFNRC), Pukyong National University, Busan, Republic of Korea.

\section{REFERENCES}

AOAC. 1995. Official methods of analysis. 16th edn. Association of Official Analytical Chemists, Arlington, Virginia, USA.

Baldisserotto, B., C. Kamunde, A. Matsuo, and C. M. Wood. 2004. A protective effect of dietary calcium against acute waterborne cadmium uptake in rainbow trout. Aquat. Toxicol. 67:57-73.

Baldisserotto, B., M. J. Chowdhury, and C. M. Wood. 2005. Effects of dietary calcium and cadmium on cadmium accumulation, calcium and cadmium uptake from water, and their interactions in juvenile rainbow trout. Aquat. Toxicol. 72:99-117.

Berntssen, M. H. G., O. O. Aspholm, K. Hylland, S. E. Wendelaar Bonga, and A. K. Lundebye. 2001. Tissue metallothionein, apoptosis and cell proliferation responses in Atlantic salmon (Salmo salar L.) parr fed elevated dietary cadmium. Comp. Biochem. Physiol. 128C:299-310.

Bokori, J. and S. Fekete. 1995. Complex study of the physiological role of cadmium. I. Cadmium and its physiological role. Acta Vet. Hung. 43:3-43.

Chowdhury, M. J. and C. M. Wood. 2007. Renal function in the freshwater rainbow trout after dietary cadmium acclimation and waterborne cadmium challenge. Comp. Biochem. Physiol. 145C:321-332.

Chowdhury, M. J., E. F. Pane, and C. M. Wood. 2004. Physiological effect of dietary cadmium acclimation and waterborne cadmium challenge in rainbow trout: respiratory, ionoregulatory, and stress parameters. Comp. Biochem. Physiol. 139C:163-173.

Cinier, C. C., M. Petit-Ramel, R. Faure, D. Garin, and Y. Bouvet. 1999. Kinetics of cadmium accumulation and elimination in 
carp, Cyprinus carpio, tissues. Comp. Biochem. Physiol. 122C:345-352.

Crespo, S., G. Nonnotte, D. A. Colin, C. Leray, L. Nonnotte, and A. Aubre. 1986. Morphological and functional alterations induced in trout intestine by dietary cadmium and lead. J. Fish Biol. 28:69-80.

Franklin, N. M., C. N. Glover, J. A. Nicol, and C. M. Wood. 2005. Calcium/cadmium interactions at uptake surfaces in rainbow trout: waterborne versus dietary routes of exposure. Environ. Toxicol. Chem. 24:2954-2964.

Galar Burgos, M. and P. S. Rainbow. 2001. Availability of cadmium and zinc from sewage sludge to the flounder, Platichthys flesus, via a marine food chain. Mar. Environ. Res. 51:417-439.

Giles, M. A. 1988. Accumulation of cadmium by rainbow trout, Salmo gairdneri, during extended exposure. Can. J. Fish. Aquat. Sci. 45:1045-1053.

Goering, P. L., M. P. Waalkes, and C. D. Klaassen. 1995. Toxicology of cadmium. In: Toxicology of Metals: Biochemical Aspects (Ed. R. A. Goyer and G. M. Cherian). Springer, New York, USA. pp. 189-214.

Goyer, R. A., C. R. Miller, S. Y. Zhu, and W. Victery. 1989. Nonmethallothionein-bound cadmium in the pathogenesis of cadmium nephrotoxicity in the rat. Toxicol. Appl. Pharmacol. 101:232-244.

Groten, J. P., E. J. Sinkeldam, J. B. Luten, and P. J. van Bladeren. 1990. Comparison of the toxicity of inorganic and liverincorporated cadmium: a 4-wk feeding study in rats. Food Chem. Toxicol. 28:435-441.

Groten, J. P., J. H. Koeman, J. H. J. van Nesselrooij, J. B. Luten, J. M. Fentener van Vlissingen, W. S. Stenhuis, and P. J. van Bladeren. 1994. Comparison of renal toxicity after long-term oral administration of cadmium chloride and cadmiummetallothionein in rats. Fundam. Appl. Toxicol. 23:544-552.

Handy, R. D. 1993. The effect of acute exposure to dietary Cd and $\mathrm{Cu}$ on organ toxicant concentrations in rainbow trout. Aquat. Toxicol. 24:1-14.

Harrison, S. E. and J. F. Klaverkamp. 1989. Uptake, elimination and tissue distribution of dietary and aqueous cadmium by rainbow trout (Salmo gairdneri Richardson) and lake whitefish (Coregonus clupeaformis Mitchill). Environ. Toxicol. Chem. 8:87-97.

Hinkle, P. M., P. A. Kinsella, and K. C. Osterhoudt. 1987. Cadmium uptake and toxicity via voltage-sensitive calcium channels. J. Biol. Chem. 262:16333-16337.

Hollis, L., J. C. McGeer, D. G. McDonald, and C. M. Wood. 1999. Cadmium accumulation, gill Cd binding, acclimation, and physiological effects during long term sublethal $\mathrm{Cd}$ exposure in rainbow trout. Aquat. Toxicol. 46:101-109.

Hollis, L., C. Hogstrand, and C. M. Wood. 2001. Tissue-specific cadmium accumulation, metallothionein induction, and tissue zinc and copper levels during chronic sublethal cadmium exposure in juvenile rainbow trout. Arch. Environ. Contam. Toxicol. 41:468-474.

IPCS (International Programme on Chemical Safety). 1992. Environmental Health Criteria 134: Cadmium. Geneva: World Health Organization.

Kay, J., D. G. Thomas, M. W. Brown, A. Cryer, D. Shurben, J. F.
Solbe, and J. S. Garvey. 1986. Cadmium accumulation and protein binding patterns in tissues of the rainbow trout, Salmo gairdneri. Environ. Health Perspect. 65:133-139.

Kim, S. G., K. H. Eom, S. S. Kim, H. G. Jin, and J. C. Kang. 2006. Kinetics of $\mathrm{Cd}$ accumulation and elimination in tissues of juvenile rockfish (Sebastes schlegeli) exposed to dietary $\mathrm{Cd}$. Mar. Environ. Res. 62:327-340.

Kraal, M. H., M. H. S. Kraak, C. J. De Groot, and C. Davids. 1995 Uptake and tissue distribution of dietary and aqueous cadmium by carp (Cyprinus carpio). Ecotoxicol. Environ. Saf. 31:179183.

Kumada, H., S. Kimura, and M. Yokote. 1980. Accumulation and biological effects of cadmium in rainbow trout. Bull. Japan Soc. Fish. Oceanogr. 46:97-103.

Lundebye, A. K., M. H. G. Berntssena, S. E. Wendelaar Bongab, and A. Maagea. 1999. Biochemical and physiological responses in Atlantic salmon (Salmo salar) following dietary exposure to copper and cadmium. Mar. Pollut. Bull. 39:137144

McGeer, J. C., C. Szebedinszky, D. G. McDonald, and C. M. Wood. 2000. Effects of chronic sublethal exposure to waterborne $\mathrm{Cu}$, $\mathrm{Cd}$ or $\mathrm{Zn}$ in rainbow trout: 1. Iono-regulatory disturbance and metabolic costs. Aquat. Toxicol. 50:231-243.

Ng, T. Y. T. and C. M. Wood. 2008. Trophic transfer and dietary toxicity of $\mathrm{Cd}$ from the oligochaete to the rainbow trout. Aquat. Toxicol. 87:47-59.

Nogami, E. M., C. M. Kimura, C. Rodrigues, A. R. Malagutti, E. Lenzi, and J. Nozaki. 2000. Effects of dietary cadmium and its bioconcentration in tilapia Oreochromis niloticus. Ecotoxicol. Environ. Saf. 45:291-295.

NRC (National Research Council). 2005. Mineral tolerance of animals. 2nd rev. ed. The National Academies Press. Washington, DC, USA. p. 86.

Pinot, F., S. E. Kreps, M. Bachelet, P. Hainaut, M. Bakonyi, and B. S. Polla. 2000. Cadmium in the environment: sources, mechanisms of biotoxicity, and biomarkers. Rev. Environ. Health 15:299-323.

Pratap, H. B., H. Fu, R. A. C. Lock, and S. E. Wendelaar-Bonga. 1989. Effects of waterborne and dietary cadmium on plasma ions of the teleost Oreochromis mossambicus in relation to water calcium levels. Arch. Environ. Contam. Toxicol. 18:568575.

Robohm, R. A. 1986. Paradoxical effect of cadmium exposure on antibody responses in two fish species: inhibition in cunners (Tautoglabrus adspersus) and enhancement in striped bass (Morone saxatilis). Vet. Immunol. Immunopathol. 12:251-262.

Roesijadi, G. and M. E. Unger. 1993. Cadmium uptake in gills of the mollusk Crassostrea virginica and inhibition by calcium channel blockers. Aquat. Toxicol. 24:195-206.

Roesijadi, G. and W. E. Robinson. 1994. Metal regulation in aquatic animals: Mechanisms of uptake, accumulation and release In: Aquatic Toxicology, Molecular, Biochemical and Cellular Perspectives (Ed. D. C. Malins and G. K. Ostrander). CRC Press, Boca Raton, Florida. pp. 387-420.

Swiergosz-Kowalewska, R. 2001. Cadmium distribution and toxicity in tissues of small rodents. Microsc. Res. Tech. 55:208-222.

Szczerbik, P., T. Mikołajczyk, M. Sokołowska-Mikołajczyk, M. 
Socha, J. Chyb, and P. Epler. 2006. Influence of long-term exposure to dietary cadmium on growth, maturation and reproduction of goldfish (subspecies: Prussian carp Carassius auratus gibelio B.) Aquat. Toxicol. 77:126-135.
Szebedinszsky, C., J. C. McGeer, D. G. McDonald, and C. M. Wood. 2001. Effects of chronic Cd exposure via the diet or water on internal organspecific distribution and subsequent gill Cd uptake kinetics in juvenile rainbow trout. Environ. Toxicol. Chem. 20:597-607.

Von Zglinicki, T., E. Edwall, E. Ostlund, B. Lind, M. Nordberg, N. R. Ringertz, and J. Wroblewski. 1992. Very low cadmium concentrations stimulate DNA synthesis and cell growth. J. Cell Sci. 103:1073-1081. 